\title{
Evaluating the Grammar Translation Method versus the Communicative Approach within the Framework of Better Foreign Language Learning Opportunities
}

\author{
Ahmed Mohamed Khair Abdalla. PhD \\ Applied Linguistics, Faculty of Sciences and Arts - Rania, Taif University, Kingdom of Saudi Arabia
}

\begin{abstract}
Considering the general educational atmosphere and the actual levels EFL students come with from secondary education, the task in this paper is to evaluate which one of the communicative and grammar translation methods, as teaching strategies, is better in providing language learning opportunities for EFL students in the branch of Taif University at Rania, Kingdom of Saudi Arabia. In order to reach tangible findings and to suggest necessary recommendations, the researcher used a questionnaire that checks on the opinions of EFL teachers about this issue. The findings were in favor of the Grammar Translation Method and supported beginning with this teaching strategy in the above mentioned branch.
\end{abstract}

Keywords: Grammar Translation ; Communicative Language Teaching ; Language Acquisition ; Communicative Competence ; accuracy ; fluency

\section{Background}

Doubtless, the overwhelming majority of people around the world are multilingual. This reality identifies foreign language acquisition as an undeniable phenomenon worldwide. It also draws the attention to the importance of creating teaching ideologies since they go hand in hand with foreign language acquisition. Such teaching ideologies represent the practical part of enhancing foreign language acquisition or learning.

Bearing in mind these considerations, this paper attempts to explore the grammar translation method (GMT) and communicative language teaching (CLT) and, as stated in the abstract, to evaluate which one of the two teaching ideologies is better in creating language learning opportunities for EFL students in the branch of Taif University at Rania.

As mentioned by Richards and Rodgers (2001), students were taught Latin in the sixteenth and seventeenth centuries by giving them a rigorous introduction of Latin grammar, a study of translation and a study of written sentences to only enhance their knowledge of grammatical structures. These aspects of language which were adopted in learning Latin became a standard way for teaching foreign languages in the eighteenth and nineteenth centuries. What matters about these aspects is their correspondence to essential language aspects which are applied by GTM. So, one can say, GTM emerged centuries ago and continued to be used in one form or another until the present time. It was first called the classical method due to its implementation in teaching Latin and Greek as classical language.

With regard to CLT, it can be traced back to the year 1960 . At that time, as maintained by Sreehari (2012), some prominent British applied linguists wrote about the theoretical basis for a communicative approach towards language teaching. Textbook writers and curriculum development centers were enthusiastic about the implementation of these theories and thus CLT rose to prominence. Most probably, the expected benefits of introducing CLT when there was an increased demand for language learning resulted in its exportation from Britain to Europe and the United States.

Chang (2011) stated that CLT has gained more importance in 1972 when Wilkins, a British applied linguist, provided an analysis of the required communicative meanings to enhance learners' understanding and ability of expression. Chang similarly explains that Wilkins classified these communicative meanings to notional and functional meanings. The notional meanings include concepts like time, sequence, quality, location and frequency; whereas, the functional meanings include concepts like requests, denials, offers and complaints. Finally, Wilkins efforts led to his book" National Syllabuses " which in turn founded for more developments of CLT.

\section{Literature Review}

\subsection{Grammar Translation Method}

As previously explained, GTM emerged a long time ago. Alam (2015) stated that GTM basically aims to help students understand and appreciate foreign language literature. GTM embraces a wide range of teaching methods and considers foreign language study as a mental discipline. Alkhuli (1983) describes GTM as a teaching method that mainly focuses on reading, writing, translating from the target language into L 1 and the use of L 1 as a major means to explain the words and structures of the target language. Alkhuli, likewise, confirms that GTM teaches and analyzes grammatical structures to ensure students' correct use of the target language. Most often, GTM prioritizes the exercises that demand students to translate disconnected sentences from the target language into 


\section{International Journal of Science and Research (IJSR) \\ ISSN (Online): 2319-7064 \\ Index Copernicus Value (2015): 78.96 | Impact Factor (2015): 6.391}

L 1. Aget (2013) provides insights into the benefits of translation as a key feature of GTM. He claims that these benefits include the consolidation of both understanding of how language works and the target language's structure for active use. These benefits also include the expansion of students vocabulary in the target language.

The results of many studies in foreign language learning and teaching certify EFL teachers' preference of GTM. For instance, Al Refaai (2013) conducted a research which examines some suggested guidelines for using GTM in foreign language learning and teaching. His results confirm that the use of GTM generally and translation in particular are preferred by EFL teachers and students since the use of L 1 in teaching alongside the target language fulfills the needs of students. Also, contemporary texts which are used in EFL classrooms, particularly at the college level, often reflect Grammar Translation principles (Baysal : 2013). I n the same context, Mondal (2012) views the application of GTM principles and traditions as suitable to the circumstances and requirements of EFL classrooms.

\subsection{Communicative language teaching}

The exact and precise definition of "Communicative Language Teaching" is not clear cut. Different EFL teachers tried to reach an understanding of this definition differently. Some EFL teachers viewed CLT as the intensive use of L2 in the language classroom, particularly oral communication. Also, while some EFL teachers regarded the adoption of CLT as a mere exchange of information between interlocutors, others understood it in its anthropological terms as a cultural-bond system for making meaning. However, the writer of this paper sees these definitions as implying an overall aim behind the use of CLT. That is, communicating through L2 to enhance its language skills simultaneously and practically. CLT regards the teaching operation as a matter of give and take. EFL students are not expected to sit bench-bound while their teachers make

thorough and unending explanations as regards their lessons. To the reverse, EFL students should genuinely contribute to the teaching operation through effective communication. Mostly, CLT considers teachers as co-communicators and facilitators of the teaching process. They should interfere limitedly and leave a greater opportunity to EFL students to communicate their ideas and treat the different phases of the lesson. Breen and Candlin (1980) emphasize that teachers in their try to enforce CLT should facilitate communication and act as independent participants in learning groups.

As stated within 2.2 above, CLT aims at improving students' communicative competence. Within communicative competence, Ansarey (2012) points out that the focus should be on functional language rather than grammar and vocabulary. Richards (2006) adopts a similar idea because he confirms that the building of CLT activities should occur away from traditional lesson formats which focus on the mastery of different grammatical items through controlled activities such as memorizing dialogues and drills. Thus, to implement an effective CLT, EFL teachers should abandon the so-called traditional lesson formats by enforcing the use of pair work activities, role plays, group work activities and project work.

\section{Methods}

The participants of the study were twenty EFL teachers in the branch of Taif University at Rania. Their academic degrees grade from bachelor to $\mathrm{PhD}$. The data collection tool was a questionnaire which consisted of 12 items. These items generally attempted to have EFL teachers' opinions about the method to be considered first in teaching the students who newly join the branch, The Grammar Translation Method or The Communicative Method. In front of each item, EFL teachers ticked the option that suites their opinion, right, or to some extent, or wrong.

\section{Data analysis and findings}

\begin{tabular}{|c|c|c|c|c|}
\hline No. & Item & Right & $\begin{array}{c}\text { To some } \\
\text { extent }\end{array}$ & Wrong \\
\hline 1 & Students begin their study in the branch of Taif university at Rania with weak levels in English. & $75 \%$ & $25 \%$ & $0 \%$ \\
\hline 2 & $\begin{array}{l}\text { Considering the actual levels of the students who newly join the branch of Taif University at } \\
\text { Rania, it is better to use The Grammar Translation Method in teaching English. }\end{array}$ & $65 \%$ & $20 \%$ & $10 \%$ \\
\hline 3 & $\begin{array}{l}\text { Considering the actual levels of the students who newly join the branch of Taif University at } \\
\text { Rania, it is better to use the communicative approach in teaching English. }\end{array}$ & $30 \%$ & $40 \%$ & $30 \%$ \\
\hline 4 & In second language acquisition, accuracy should precede fluency. & $90 \%$ & $5 \%$ & $5 \%$ \\
\hline 5 & To communicate skillfully, students need to be accurate in using the language. & $80 \%$ & $10 \%$ & $10 \%$ \\
\hline 6 & To communicate skillfully, students don't need to be accurate in using the language. & $10 \%$ & $15 \%$ & $75 \%$ \\
\hline 7 & $\begin{array}{c}\text { Because The Grammar Translation Method maintains L } 1 \text { as the reference system in learning L } \\
2 \text {, it should be given the priority in teaching English to the students who newly join the branch } \\
\text { of Taif university at Rania. }\end{array}$ & $75 \%$ & $25 \%$ & $0 \%$ \\
\hline 8 & $\begin{array}{c}\text { Because The Grammar Translation Method lays emphasis on translation, students can never } \\
\text { emancipate themselves form dependence on L } 1 .\end{array}$ & $25 \%$ & $65 \%$ & 10 \\
\hline 9 & Teaching grammar founds for developing the language skills. & $60 \%$ & $25 \%$ & $15 \%$ \\
\hline 10 & $\begin{array}{l}\text { Elaborate explanations of grammatical rules facilitate students task to identify how words are } \\
\text { used together in sentences. }\end{array}$ & $75 \%$ & $15 \%$ & $10 \%$ \\
\hline 11 & It is indispensable in CLT to use authentic and meaningful expressions. & $90 \%$ & $10 \%$ & $0 \%$ \\
\hline 12 & $\begin{array}{l}\text { The immediate implementation of CLT in the branch of Taif University can be inefficient } \\
\text { because the students who newly join the branch are usually unable to produce authentic and } \\
\text { acceptable expressions in the everyday life of communication and interaction. }\end{array}$ & $70 \%$ & $30 \%$ & $0 \%$ \\
\hline
\end{tabular}

Volume 6 Issue 1, January 2017 www.ijsr.net 


\section{International Journal of Science and Research (IJSR) \\ ISSN (Online): 2319-7064}

Index Copernicus Value (2015): 78.96 | Impact Factor (2015): 6.391

\section{Participants responses in percentage terms}

With respect to the items in the above questionnaire, item one confirms that students begin their study in the branch of Taif University with weak levels in English, while item two, in view of this reality, states that GTM should be considered first in teaching those students. $75 \%$ of the participants were in favor of the first item's opinion, while $65 \%$ agreed with the second item's opinion. In fact, students start university education with a preparatory year during which they study English as one of the essential prescribed courses. Sure enough, students have weaknesses in English language because they, most often, do not perform well in the end-ofsemester English language examinations. This raises the central question of the present paper, which of the two teaching methods to be considered first in teaching English language. The researcher, like the majority of participants, advocates starting with GTM because it predisposes an educational atmosphere for a deliberate development of the language skills. Some dogmatic critics argue against GTM and view it as an out of date teaching strategy that should be abandoned. However, the researcher believes that new teaching strategies can never completely invalidate or replace older ones. $30 \%$ of the participants supported the idea of item three. That is, beginning with CLT. Item four and item five, sequentially, view that accuracy should precede fluency in second language acquisition and students need to be accurate in order to communicate skillfully. In comparison with fluency, participants were almost unanimous about the priority that should be given to accuracy in second language acquisition (90\%). Also, participants were almost unanimous about the necessity of accuracy to effective communication. ( $80 \%$ ). Only $10 \%$ of the participants underestimated the necessity of accuracy to effective communication ( item six ). Participants opinion about accuracy denote their preference of GTM because one understanding of accuracy is grammatical correctness and as known grammatical correctness is a main principle of GTM. As clarified in item seven, GTM maintains L 1 as the reference system in learning L 2. Thus, it should be given the priority in teaching English for the students who newly join the branch of Taif University at Rania. $75 \%$ of the participants were in favor of this opinion. This opinion, in particular, shows an advantage of GTM over CLT. Consequently, the high percentage of participants who were in agreement about it, also, shows their direct preference of GTM. Item eight required participants' point of view as regards a possible shortcoming of GTM since it can't emancipate students from dependence on L 1 due to its overemphasis on translation. $25 \%$ percent of the participants agreed with this opinion, $65 \%$ were neutral, while $10 \%$ disagreed with it. despite the limited percentage of disagreement with the opinion of item eight, still, the percentage of neutrality hints at participants preference of GTM. Item nine states that teaching grammar founds for a general development of the language skills, while item 10 certifies how the elaborate explanation of grammatical rules can facilitate students task to identify the formulation of words in sentences. According to the sequence of these items, the percentage of agreement was $60 \%$ and $75 \%$. This, once again, shows participants' advocacy of GTM. For a successful implementation of CLT, item eleven suggests the necessity of using authentic and meaningful expressions by students. $90 \%$ of the participants agreed with this opinion. Indeed, the use of authentic and meaningful expressions needs the prior implementation of GTM since, as previously stated, it provides a deliberate study of the language. This deliberate study of the language establishes for acquiring authentic and meaningful expressions. By comparison with item $11,70 \%$ of the participants approved of the idea in item twelve with respect to the inefficiency of an immediate implementation of CLT in Rania Branch since the students who newly join this branch are usually unable to produce authentic and acceptable expressions in the everyday life of communication and interaction.

With reference to the previous analysis, the results of this paper are crystal clear. They show participants' approval of a prior implementation of GTM to CLT in the branch of Taif University at Rania. As known, EFL teachers can vary their teaching strategies by shifting from a teaching strategy to another or even by adopting an eclectic way of teaching. Thus, GTM and CLT can be viewed as complementary to each other. An implementation of CLT can follow the prior implementation of GTM after students lay the foundations for concrete language skills. These concrete language skills will definitely pave the way for a successful use of CLT.

\section{References}

[1] Alkhuli A. (1983). English as a Foreign Language : Linguistic Background and Teaching Methods. Ministry of Education. Kingdom of Saudi Arabia.

[2] Ansarey D. (2012). Communicative Language Teaching in EFL Contexts : Teachers Attitude and Perception in Bangladesh. ASA University Review. Vol. 6. No. 1.

[3] Aget I A. (2013). The Effects of Using Grammar Translation Method on Acquiring English as a Foreign Language. International Journal of Asian Social Science. 2469-2476

[4] Al Refaai K I. (2013). Suggested Guidelines for Using Translation in Foreign Language Learning and Teaching. Educational Research. International Research Journals.

[5] Alam M M. (2015). Comparative Acceptability of GTM and CLT to the Teachers of Rural Secondary High School in Bangladesh. Global Journals Inc. (USA) Volume 15. Issue 4. Version 1.0.

[6] Ahmed S \& Rao C. (2013). Applying Communicative Approach in Teaching English as a Foreign Language : A Case Study of Pakistan. China. ISSN: 1697-7467.

[7] Baysal D. (2013). A Brief History of Language Teaching : The Grammar Translation Method. Educational Technology.

[8] Breen M P. \& Candlin C. (1980). The Essentials of a Communicative Curriculum in Language Teaching. Applied Linguistics.

[9] Belchamber R. (2007). The Advantages of Communicative Language Teaching. The Internet Tesl Journal. Vol. x111. No. 2.

[10]Chang S C. (2011). A Contrastive Study of Grammar Translation Method and Communicative Approach in Teaching English Grammar. English Language Teaching. Vol. 6.No. 1.

[11]Lai H. (2010). Gender Effect on the Use CSs. English Language Teaching. Vol. 3. No. 4. 


\section{International Journal of Science and Research (IJSR) \\ ISSN (Online): 2319-7064 \\ Index Copernicus Value (2015): 78.96 | Impact Factor (2015): 6.391}

[12]Littlewood W. (2013). Developing a Context-sensitive Pedagogy for Communication-oriented Language Teaching. Hong Kong Baptist University.

[13] Mondal N K. (2012). A Comparative Study of Grammar Translation Method and Communicative Approach in Teaching English Language. New York Science Journal.
[14]Richards J C. (2006). Communicative Language Teaching Today. Cambridge University Press. Printed in the United States.

[15]Richards J C \& Rodgers T S. (2001). Approaches and Methods in Language Teaching. Cambridge University Press. Printed in the United States of America.

[16] Sreehari P. (2012). Communicative Language Teaching : Possibilities and Problems. Published by the Canadian Centre of Science and Education. Vol. 5. No. 12.

\begin{tabular}{|c|c|c|c|c|}
\hline \multicolumn{5}{|c|}{ Appendix } \\
\hline No & Item & Right & $\begin{array}{c}\text { To some } \\
\text { extent }\end{array}$ & Wrong \\
\hline 1 & Students begin their study in the branch of Taif university at Rania with weak levels in English. & & & \\
\hline 2 & $\begin{array}{l}\text { Considering the actual levels of the students who newly join the branch of Taif University at } \\
\text { Rania, it is better to use The Grammar Translation Method in teaching English. }\end{array}$ & & & \\
\hline 3 & $\begin{array}{l}\text { Considering the actual levels of the students who newly join the branch of Taif University at } \\
\text { Rania, it is better to use the communicative approach in teaching English. }\end{array}$ & & & \\
\hline 4 & In second language acquisition, accuracy should precede fluency. & & & \\
\hline 5 & To communicate skillfully, students need to be accurate in using the language. & & & \\
\hline 6 & To communicate skillfully, students don't need to be accurate in using the language. & & & \\
\hline 7 & $\begin{array}{c}\text { Because The Grammar Translation Method maintains L } 1 \text { as the reference system in learning L 2, } \\
\text { it should be given the priority in teaching English to the students who newly join the branch of } \\
\text { Taif University at Rania. }\end{array}$ & & & \\
\hline 8 & $\begin{array}{l}\text { Because The Grammar Translation Method lays emphasis on translation, students can never } \\
\text { emancipate themselves from dependence on L } 1 .\end{array}$ & & & \\
\hline 9 & Teaching grammar founds for developing the language skills. & & & \\
\hline 10 & $\begin{array}{c}\text { Elaborate explanations of grammatical rules facilitate students task to identify how words are } \\
\text { used together in sentences. }\end{array}$ & & & \\
\hline 11 & It is indispensable in CLT to use authentic and meaningful expressions. & & & \\
\hline 12 & $\begin{array}{l}\text { The immediate implementation of CLT in the branch of Taif University can be inefficient because } \\
\text { the students who newly join the branch are usually unable to produce authentic and acceptable } \\
\text { expressions in the everyday life of communication and interaction. }\end{array}$ & & & \\
\hline
\end{tabular}

